\title{
Direito entre dominação de classe e racionalidade em Franz Neumann
}

\author{
Andréa Monteiro Dalton ${ }^{1}$ \\ João Paulo Mansur ${ }^{2}$
}

\section{Resumo}

O Terceiro Reich provocou traumáticos reflexos na filosofia jurídica e política de Franz Neumann. Sob influência do materialismo histórico-dialético marxista, o filósofo compreendia o direito como o reconhecimento oficial das relações sociais e econômicas surgidas com o capitalismo. Mas, ao mesmo tempo, o regime ditatorial nazista e as transformações por que passava a técnica jurídica, ambos possibilitados pelo capitalismo monopolista, o faziam enaltecer o direito liberal da época do capitalismo concorrencial, que possuía o que o filósofo chamava de "mínimo de racionalidade". Este trabalho parte dessa tensão na filosofia jurídica de Neumann, que critica o direito como dominação de classe, mas também enxerga nele uma dimensão positiva devido à sua possibilidade de "racionalidade". O artigo aponta as virtudes de Neumann por elaborar sua filosofia jurídica de forma materialista e termina, criticamente, com base em Marx e Lênin, assinalando as suas contradições e insuficiências.

Palavras-chave: Franz Neumann; Direito; Marxismo; Imperialismo; Leninismo.

\section{Introdução.}

Há uma tensão no pensamento do filósofo alemão Franz Neumann que remonta à sua experiência de vida com o nazismo do Terceiro Reich. Se, por um lado, enquanto membro do

\footnotetext{
${ }^{1}$ Assistente Social. Mestre em Serviço Social (PUC-Rio). Doutora em Serviço Social (UFRJ). Professora adjunta do Departamento de Serviço Social da Universidade Federal do Espírito Santo. Membro do Grupo de Estudos Interfaces - Teoria Social, Serviço Social e Politica Social. Instituição: Universidade Federal do Espírito Santo. Brasil. E-mail: andreadaltonas@gmail.com

${ }^{2}$ Doutorando em Direito pela Universidade Federal de Minas Gerais. Mestre em direito pela Universidade Federal de Minas Gerais (2017). Especialista em Teoria e Filosofia do Direito pela Pontifícia Universidade Católica de Minas Gerais (2017). Graduado em Direito pela Universidade Federal do Espírito Santo (2014). Graduando em Ciências Sociais pela Universidade Federal do Espírito Santo. Membro do Studium Iuris (UFMG), Grupo de Pesquisa em História do Direito. Contato: jpmansur@gmail.com
} 
Instituto de Pesquisa Social, centro crítico de pesquisas voltado ao projeto da emancipação humana, Neumann desenvolvia críticas ao direito liberal burguês valendo-se de aproximações com o marxismo, por outro lado, o regime ditatorial e imperialista alemão levou-o a reavaliar o potencial emancipador do mesmo. Neumann, diante das disputas teóricas existentes no interior do Instituto de Pesquisas Sociais, afastava-se dos pensadores mais críticos da sociedade burguesa, como Horkheimer e Adorno, para se alinhar a Otto Kirchheimer na tentativa de reconciliar teoricamente o direito liberal e as aspirações de emancipação do homem³ ${ }^{3}$ como já bem percebeu Willian F. Scheuerman:

In some distinction to Max Horkheimer, Theodor Adorno, and Herbert Marcuse, however, the experience of fascism simultaneously cemented Neumann's and Kirchheimer's appreciation for a series of liberal legal and political institutions. (...) This also helps explain the real tensions that existed between Neumann and Kirchheimer and theorists such as Horkheimer and Adorno (SCHEUERMAN, 1996, p.2-3).

Essa tensão de seu pensamento manifestava-se em termos jurídicos, políticos, e econômicos, e, evidentemente, na relação entre eles. Com Marx, como se verá mais detidamente à frente, Neumann compreendia que "os homens fazem a sua própria história, mas não a fazem segundo a sua livre vontade; não a fazem sob circunstâncias de sua escolha e sim sob aquelas com que se defrontam diretamente, legadas e transmitidas pelo passado" (MARX, 2001, p.21). Por isso, a análise das determinações da realidade da sociedade burguesa e do atual estágio do modo de produção capitalista são seus pontos de partida para a compreensão da política e do direito nazista. No Behemoth, quando o filósofo alemão estudou a estrutura e a prática do nacional socialismo, Neumann descreveu-as, em linha marxista, com relação à configuração das classes sociais alemãs existentes na decadência da República de Weimar e com relação à mudança da forma do modo de produção capitalista, de concorrencial para monopolista. O desenvolvimento do capitalismo monopolista seria responsável por transformações na forma jurídica, teoria que o autor desenvolveu principalmente nos textos $A$ mudança de função da lei no direito da sociedade burguesa e $O$ conceito de liberdade política. Os antigos conceitos jurídicos determinados, forma liberal do direito que predominou no capitalismo concorrencial, atendendo aos interesses da burguesia concorrencial, foram, em parte, substituídos por cláusulas indeterminadas, alusões a

\footnotetext{
${ }^{3}$ Os dois grupos também destoavam no modo de aproximação adotado ao pesquisarem o nazismo: "Em resumo, pode-se dizer que o Institut empregou duas abordagens gerais em sua análise do nazismo. Uma, associada a Neumann, Gurland e Kirchheimer, concentrou-se nas mudanças havidas nas instituições jurídicas, políticas e econômicas, olhando só de passagem a psicologia social ou a cultura de massas. Seus pressupostos fundamentais eram os de um marxismo mais ortodoxo [comente-se: nem tanto, como se mostrará neste artigo], que destacava a centralidade do capitalismo monopolista, [...]. A outra abordagem, adotada pelo grupo de Horkheimer, viu o nazismo como o exemplo extremo de uma tendência global para a dominação irracional no Ocidente" (JAY, 2008, p.220).
} 
equidade e medidas executivas individuais, forma jurídica que expressaria os interesses dos monopolistas.

Não obstante a análise do real próxima ao materialismo histórico-dialético marxista e a conseqüente crítica ao direito, Neumann iria, contraditoriamente, no pós-guerra - momento prérevolucionário que poderia ter ensejado a tomada do poder pelos operários alemães - propor uma política de desnazificação com objetivo de restauração da democracia burguesa na Alemanha e com propostas de reformas econômicas em uma política antitruste e antimonopólios que visava restabelecer o capitalismo concorrencial. Seu projeto, ao pretender retirar a interferência da grande indústria monopolista causadora do imperialismo nazista, almejava fortalecer o chamado Estado de Direito, ou, em seus termos, o Império das Leis (NEUMANN, 2013, p.114), e restaurar um suposto "mínimo de racionalidade" que o autor afirmava existir na época de predominância no direito liberal com os conceitos jurídicos determinados.

Este trabalho mergulha nessa tensão do pensamento de Neumann, que compreende o direito como dominação de classe, mas também como potencialmente possibilitador de um "mínimo de racionalidade"; demonstra as virtudes de sua análise histórico-materialista do direito e, ao término; aponta a sua contradição principal: a tentativa de girar a roda da história para trás com o objetivo de retornar ao capitalismo concorrencial e, em consequência, de (re)abrir possibilidades materiais para o direito liberal. O capitalismo, como se verá com Lênin, é, porém, monopolizador. Crer na vontade política para restaurar o capitalismo concorrencial e, por conseguinte, o direito liberal, é puro idealismo. O próprio Neumann utilizava a categoria "voluntarismo utópico" para censurar posturas filosóficas que desconsideram as relações sociais e econômicas do momento histórico. Apesar de materialista, as artimanhas do reformismo capturaram Neumann.

\section{$2 \mathrm{O}$ modo de pesquisa histórico-materialista da filosofia jurídica de Franz Neumann.}

Desde meados da década de 30, Franz Neumann começara a desenvolver sua filosofia jurídica relacionando o direito às relações sociais e econômicas das determinadas épocas históricas. No texto $A$ mudança da função do direito na sociedade moderna, Neumann criticava a inserção de cláusulas indeterminadas e alusões a noções de equidade no direito alemão. Essa mudança da forma jurídica estaria relacionada ao fim do capitalismo concorrencial, que, outrora durante sua existência, pela disputa econômica entre grande número de capitalistas, exigiria do direito igualdade formal, texto semanticamente determinado e universalidade na aplicação, visando permitir o cálculo da previsibilidade e a certeza da exequibilidade das leis e dos contratos. 
Em sua visão, portanto, existiria uma clara relação entre o capitalismo concorrencial e a forma jurídica liberal dos conceitos jurídicos determinados, aquele enquanto condição de existência destes.

Em termos marxianos, que Neumann bem os compreendia, "o Direito nunca pode ultrapassar a forma econômica e o desenvolvimento cultural, por ela condicionado, da sociedade" (MARX; ENGELS, 2010, p.31). Nas palavras de Neumann no citado texto A mudança da função do direito na sociedade moderna, eis a relação entre a forma jurídica pós-revolução francesa, marcada pelo Império da lei, e a concorrência capitalista:

(...) A teoria do império da lei também é necessária para a satisfação das condições de concorrência capitalista. A necessidade de previsibilidade e de confiança no sistema jurídico e na administração realmente foi um dos motivos para a limitação do poder dos príncipes [...]. A livre concorrência necessitava da lei universal porque ela é a forma mais acabada da racionalidade formal e, ao mesmo tempo, porque ela também precisa exigir a submissão absoluta do juiz à lei e, assim, à divisão dos poderes. A livre concorrência está condicionada à existência de um grande número de competidores com aproximadamente a mesma força, que concorrem em um mercado livre. Liberdade do mercado de produtos, liberdade do mercado de trabalho, livre seleção no interior da classe empresarial, liberdade contratual e, sobretudo, previsibilidade do Judiciário são as características essenciais do sistema liberal de concorrência, que, por meio de uma empresa capitalista racional e contínua, quer de fato gerar lucro e lucro sempre renovado (NEUMANN, 2014, p.43, grifos nossos).

O capitalismo monopolista, momento em que, pela formação de holdings, trustes, cartéis e monopólios da grande indústria, se perdia de vista a concorrência capitalista dos tempos anteriores, trouxe, na interpretação de Neumann, consequências ao direito com a inserção de cláusulas indeterminados e de juízos de equidade, em detrimento à lei geral, abstrata e formalmente impessoal dos conceitos jurídicos determinados. Esses novos instrumentos jurídicos serviam como "escapes" para a satisfação dos interesses dos monopolistas, em detrimento aos pequenos e médios burgueses, aos trabalhadores e aos consumidores. Para atender a essas necessidades do capital monopolista e financeiro, medidas individuais do executivo também teriam ganhado maior espaço frente à lei em sentido estrito. Tal hipertrofia do executivo, na Alemanha, contribuiu para o desenvolvimento do regime ditatorial e imperialista do Terceiro Reich. Assim, Neumann explicitava as determinações do Direito em função das relações sociais, das condições de vida existentes na sociedade civil burguesa e do estágio do modo de produção capitalista, concorrencial ou monopolista.

Neumann percebia, portanto, a relação existente entre as instituições jurídicas e políticas na modernidade liberal pós-revolução francesa e as necessidades da burguesia concorrencial em formatar as instituições jurídicas frente às exigências do mercado, e não com referência a idealismos de formas puras de pensamento, como faria uma historiografia hegeliana ou de outras 
matrizes idealistas: alusões grosseiras a Caio e Tício nos jargões jurídicos, aos dois homens fundadores da sociedade que, com vontade livre e com base em contrato, restringiriam seus arbítrios - para fazer alusão em termos gerais a Rousseau, Kant e Dühring -, entre outras "Robinsonadas" jurídicas. Na citação abaixo, na qual Engels rechaça a fillosofia jurídica de Dühring, é possível notar a diferença entre o modo jurídico de pesquisa que Neumann desenvolve em perspectiva histórico-materialista em relação a estudos que se valem de modelos idealistas e axiomáticos.

O sr. Düring, portanto, decompõe a sociedade em seus elementos mais simples e descobre que a sociedade mais simples é constituída de, no mínimo, dois tipos humanos. Dali por diante, ele opera axiomaticamente com esses dois tipos. E, então, apresenta-se com naturalidade o axioma moral básico: "Duas vontades humanas são como tais totalmente iguais, e, num primeiro momento, não podem exigir em termos positivos nada uma da outra". Com isto, está "caracterizada a forma básica da justiça moral"; e também a da jurídica, pois "para desenvolver os conceitos jurídicos fundamentais tudo do que precisamos é a relação bem simples e elementar entre dois seres humanos". [...]. Para conseguir compor o axioma básico de que dois seres humanos e suas vontades são totalmente iguais e não podem exigir nada um do outro, não podemos de modo algum usar dois homens quaisquer escolhidos a esmo. É preciso que sejam dois seres humanos tão desligados de toda a realidade, de toda as relações nacionais, econômicas, políticas e religiosas, de todas as particularidades sexuais e pessoais existentes na Terra, que tanto um como o outro nada sobre além do simples conceito de "ser humano"; então eles, de fato, serão "totalmente iguais". Eles serão, portanto, dois completos fantasmas, conjurados pelo mesmo sr. Dühring que, em toda parte, fareja e denuncia atividades "espiritualistas" (ENGELS, 2015, p.127129).

Para satisfazer às necessidades da burguesia concorrencial, Neumann (2014, p.44 e ss.) afirmava que o direito pós-revolução francesa precisava se fazer racional e formal, válido universalmente a todos os homens. Em primeiro lugar, isso implicava atuar por regras gerais, aplicáveis igualmente a todo e qualquer caso semelhante. Também significava que o direito não poderia veicular medidas individuais. Caso contrário, se prejudicaria a igualdade entre os competidores. Da mesma forma, a racionalidade formal vedava à lei jurídica força retroativa. Uma vez conhecidos os fatos de antemão à promulgação da lei geral, qualquer regra que retroagisse não apenas afetaria a segurança jurídica dos burgueses, mas também a impessoalidade da norma, posto que seriam conhecidos os destinatários previamente. Além disso, o espaço de apreciação do juiz deveria ser o mínimo possível para que se pudesse garantir a calculabilidade do burguês e a execução rígida do direito legal e/ou contratual. O texto legal, portanto, não poderia ter alusões a equidade, nem conceitos indeterminados, ambos impregnados de vagueza semântica, que implicam interpretações subjetivas e possivelmente distintas para casos jurídicos semelhantes.

Nessa análise do direito burguês alinhada, até o momento, ao materialismo marxiano, "o Direito nada mais é do que o reconhecimento oficial do fato" (MARX, 2017, p.84). Até a mais 
alta abstração da racionalidade formal, que foi o liberalismo político-filosófico, com suas noções de segurança e igualdade jurídica, deve ser compreendida a partir das possibilidades legadas pela história, no caso, pelo capitalismo concorrencial. Consciente de seu modo de pesquisa históricomaterialista, Neumann explicitamente negava o que chamou de "voluntarismo utópico", a concepção histórica de que o homem, em atitude individual ou política, pode agir independentemente das condições dadas pela história:

Caso ressaltemos a supremacia da ação política a despeito da situação história no interior da qual a realidade deve ser realizada, chegamos a um voluntarismo utópico (utopian putschism) - a visão de que o homem pode, em qualquer momento histórico, ou mesmo a despeito do momento histórico, realizar completamente sua liberdade por meio de sua ação (NEUMANN, 2013, p.144).

O "voluntarismo utópico" partilha das críticas marxistas ao idealismo filosófico, a partir do qual as teorias puramente jurídicas criam suas "robinsonadas". Em A ideologia Alemã, texto de 1846, Marx e Engels, ironizando a atitude dos juristas, expunham o seguinte:

Como o Estado é a forma na qual os indivíduos de uma classe dominante fazem valer seus interesses comuns e que sintetiza a sociedade civil inteira de uma época, segue-se que todas as instituições coletivas são mediadas pelo Estado, adquirem por meio dele uma forma política. Daí a ilusão, como se a lei se baseasse na vontade e, mais ainda, na vontade separada de sua base real [realen], na vontade livre. Do mesmo modo o direito é reduzido à lei. O direito privado se desenvolveu simultaneamente com a propriedade privada, a partir da dissolução da comunidade natural. [...] A partir dessa mesma ilusão dos juristas explica-se que, para eles e para todos os códigos jurídicos em geral, seja algo acidental que os indivíduos estabeleçam relações uns com os outros, contratos por exemplo, que essas relações sejam consideradas como relações que [podem] ser estabelecidas ou não a depender da vontade, e cujo conteúdo [rep]ousa inteiramente sobre o [arb]itrio individual dos contratantes (MARX; ENGELS, 2017, p.76-77, grifos nossos).

No texto $O$ conceito de liberdade politica, publicado em 1950, posterior, portanto, ao $A$ mudança da função do direito na sociedade moderna, Neumann desenvolveu mais pormenorizadamente a tese da relação entre a estrutura formal do direito liberal pós-revolução francesa e o capitalismo concorrencial:

[...] a estrutura formal do direito é igualmente decisiva na operação do sistema social de uma sociedade competitivo-contratual. A necessidade dos sistemas administrativo e jurídico proverem calculabilidade e segurança foi uma das razões da limitação do poder da monarquia patrimonial e do feudalismo. Essa limitação culminou no estabelecimento do poder legislativo dos parlamentos por meio dos quais as classes médias controlaram o aparato fiscal e administrativo e exerceram um domínio, conjunto coma coroa, sobre as mudanças do sistema jurídico. Uma sociedade competitiva requer leis gerais como a forma mais elevada de racionalidade instrumental porque essa sociedade é composta por um grande número de empresários de poder econômico equivalente. Liberdade no mercado de bens consumíveis, liberdade do mercado de trabalho, livre acesso 
à classe empresarial, liberdade contratual e a racionalidade das respostas judiciais em litígios - essas são as características essenciais de um lucro sempre renovado, em uma empresa capitalista contínua e racional. A principal tarefa do estado é a criação de uma ordem jurídica que assegurará o cumprimento das obrigações contratuais; a expectativa de que obrigações contratuais serão respeitadas deve ser calculável. Essa calculabilidade somente pode ser alcançada se as leis são gerais em sua estrutura - contanto que exista certa igualdade de poder entre os competidores, de tal modo que cada um possua interesses idênticos. A relação entre o estado e empresário, particularmente no que diz respeito às obrigações fiscais e interferências em direitos de propriedade, também devem ser tão calculável quanto possível. O soberano não pode elevar os impostos nem restringir o exercício da atividade empresarial sem uma lei geral, uma vez que uma medida individual necessariamente prefere um ao outro $e$, assim, viola o princípio da igualdade empresarial (NEUMANN, 2013, p 119120 , grifos nossos).

Neumann concluía em 1937:

A estrutura material do sistema jurídico [baseado em conceitos jurídicos determinados]: Esse sistema jurídico estava economicamente vinculado à livre concorrência. Ela encontrava sua expressão nas garantias conexas da propriedade e nas liberdades de contrato e de comércio (NEUMANN, 2014, p. 54 , grifos nossos).

Importante comparar as duas passagens acima de Neumann a Marx, em especial atenção a $O$ capital, em que direitos de liberdade e igualdade são expressões das relações econômicas do modo capitalista de produção e circulação de mercadorias:

A esfera da circulação ou da troca de mercadorias, em cujos limites se move a compra e a venda da força de trabalho é, de fato, um verdadeiro Éden dos direitos inatos do homem. Ela é o reino exclusivo da liberdade, da igualdade, da propriedade e de Bentham. Liberdade, pois os compradores e vendedores de uma mercadoria, por exemplo, da força de trabalho, são movidos apenas por seu livre-arbítrio. Eles contratam como pessoas livres, dotadas dos mesmos direitos. O contrato é o resultado, em que suas vontades recebem uma expressão legal comum a ambas as partes. Igualdade, pois eles se relacionam um com o outro apenas como possuidores de mercadorias e trocam equivalente por equivalente. Propriedade porque cada um dispõe do que é seu (MARX, 2017, p.250-251).

Engels e Kautsky, em $O$ socialismo jurídico, abstraindo a teoria do valor da exposição, deixam em tons mais simples a filosofia marxista sobre o direito: "Além disso, uma vez que a concorrência, forma fundamental das relações entre livres produtores de mercadorias, é a grande niveladora, a igualdade jurídica tornou-se o principal brado de guerra dos burgueses". (ENGELS, KAUTSKY, 2012, p.19).

Sendo expressão legal da propriedade, a dominação de classe que se oficializa através do direito legal e contratual está patente na filosofia jurídica de Neumann. Eis a crítica às mais variadas teorias jurídicas tradicionais, segundo as quais o direito garantiria a emancipação de todos os indivíduos. Neumann desenvolvia ainda outra crítica ao direito liberal instituído após a 
revolução francesa: o filósofo alemão afirmava que a racionalidade formal do direito liberal burguês exercia uma função ideológica nociva: a universalidade da lei seria responsável por encobrir o poder da burguesia sobre o direito e sobre o Estado (NEUMANN, 2014, p.47). A universalidade da lei, aparência sensível do direito, encobre seu conteúdo de classe dado na essência.

\section{A "racionalidade" do direito liberal existente no capitalismo concorrencial.}

Não obstante Franz Neumann analisasse de modo materialista a gênese do direito enquanto produto das relações sociais e econômicas do capitalismo concorrencial e expusesse criticamente a dominação classista que a ideologia da universalidade jurídica encobria [e anda encobre], o filósofo alemão sustentava que essa universalidade formal das leis também possuiria um caráter normativo importante, que visava garantir um mínimo de igualdade e liberdade aos cidadãos, tarefa que, segundo ele, "transcendia a livre concorrência", ou seja, a "oficialização jurídica do capitalismo".

A universalidade da lei e a independência do juiz garantem um mínimo de liberdade pessoal e política. A lei universal estabelece a igualdade entre as pessoas. Ela é a base para interferências na liberdade e na propriedade. É por isso que o caráter da lei a que devem ser reduzidas todas as intervenções é de significado decisivo. A liberdade apenas é garantida quando intervenções como essas puderem ser reduzidas à lei universal e, assim, quando o princípio da igualdade for garantido. A frase de Voltaire de que liberdade significa não ser dependente de nada além da lei leva em conta apenas a lei universal. Se o soberano pode decretar medidas individuais, se pode prender essa ou aquela pessoa, confiscar essa ou aquela propriedade, isso acontece contra a verdadeira independência dos juízes. O juiz que deve executar medidas individuais como essa se torna mero policial e oficial de justiça. É por isso que a verdadeira independência pressupõe o império do Estado por meio de leis universais. A lei universal, a independência dos juizes, bem como a doutrina da divisão dos poderes têm, portanto, tarefas que transcendem a necessidade da livre concorrência. (NEUMANN, 2014, p.47, grifos nossos).

Qual seja, na filosofia de Neumann, apesar de o Estado de Direito [ou Império das Leis] encontrar sua gênese no capitalismo e de sua função ser oficializar a concorrência contratual e a propriedade privada dos meios de produção, duas funções expostas da seção anterior deste artigo, a lei universal e formalmente impessoal garantiria um mínimo moral de liberdade e igualdade, algo que, para Neumann, deveria ser valorizado.

Eis aqui a tensão da filosofia jurídica de Neumann de que já falamos acima: o direito, enquanto veículo de leis universais, situa-se entre dominação de classe e racionalidade. Assim: "Todas as três funções da universalidade - encobrir o poder da burguesia, tornar o sistema vol.12,nº.02,Riode Janeiro,2019. pp. 401-423 408 
econômico previsível e garantir um mínimo de liberdade e igualdade - são decisivas e não apenas a segunda [...]" (NEUMANN, 2014, p. 47). Comentando essa tensão, Postone expôs:

Franz Neumann também considerou serem positivos os elementos do Estado constitucional liberal. Embora as leis gerais formais possam ter obscurecido a dominação da classe burguesa enquanto tornavam calculável o sistema econômico, de acordo com Neumann, o caráter geral da lei, a independência do judiciário e a separação dos poderes promoviam e protegiam a liberdade individual e a igualdade. Ele argumentava que esses elementos da ordem liberal não precisavam e nem deveriam ser abolidos com a reviravolta do capitalismo (POSTONE, 2008, p. 207).

Traumatizado com o virulento regime nazista, que se instrumentalizava juridicamente com medidas individuais do Führer e por conceitos jurídicos indeterminados, Neumann valorizava a generalidade da lei [dos conceitos determinados], que, para ele, garantiria um mínimo de razão e que restringiria o poder estatal sobre os indivíduos.

[...]. O Estado pode intervir na liberdade do indivíduo - mas primeiro deve provar que pode fazer isso. Esta prova só pode ser deduzida por referência ao "direito" e deve, como regra, ser submetida a órgãos específicos do Estado: cortes ou tribunais administrativos. Existem, portanto, três afirmações inerentes à análise dos direitos civis: $\mathrm{O}$ ônus da prova pela intervenção é sempre do Estado; O único meio de prova é referência a uma lei; O método pelo qual uma decisão deve ser alcançada é regulado pelo direito. (NEUMANN, 2013, p. 112).

Aqui, ao lado das duas censuras ao direito liberal feitas em tom de uma "teoria jurídica crítica", Neumann deliberadamente acolhe toda uma tradição liberal de uma "teoria jurídica tradicional”. Com Locke (1998, p. 461), por exemplo, Neumann aceitaria dizer que o Estado cujo soberano possui prerrogativas absolutistas continuaria em Estado de Natureza, tendo em vista a ausência de limites ao arbítrio do mesmo. Sua filosofia, porém, rejeitava o naturalismo de Locke ao enfatizar o aspecto formal da generalidade da lei enquanto um mínimo racional. "Direito natural secularizado", posto que formal, foi o termo escolhido pelo alemão para expor os limites à soberania estatal sem referência a direitos anteriores à ordem jurídico-estatal. Aqui a principal influência de Neumann é Weber com a análise da sociedade capitalista e seu "processo de racionalização". Neumann, assim como outros pensadores de Frankfurt, a exemplo de Otto Kirchheimer, operacionalizava uma conciliação entre Marx e Weber:

Assim, a definição de Hobbes-Austin-Kelsen é correta, traduzindo o conceito de soberania em termos legais. Direito é simplesmente voluntas, ou vontade. Mas historicamente existe uma segunda definição [de direito], que faz referência à estrutura formal do direito positivo e que enfatiza sua generalidade. Se o direito fosse somente voluntas, o conceito de "império do direito" (rule of law) não teria qualquer significado verificável para a proteção dos direitos individuais, porque soberania e direito seriam, então, sinônimos. Na verdade, existe uma sólida tradição, cujas origens remontam a Platão e Aristóteles, que defende que, 
a despeito do conteúdo do direito, sua forma deve ser geral (ou universal, como é nomeada algumas vezes). Mesmo quando o direito natural é rejeitado, a insistência sobre a estrutura formal do direito sobrevive como um requerimento mínimo da razão para impor restrições ao poder. A generalidade da lei pode então ser chamada de direito natural secularizado. (NEUMANN, 2013, p.114, grifos nossos).

Foi essa garantia de um mínimo de igualdade e de liberdade presente no direito liberal através dos conceitos determinados, válidos formalmente na generalidade a todos os indivíduos, que fazia que Franz Neumann enxergasse com desgosto a inserção de cláusulas indeterminadas, de noções de equidade e das medidas individuais no direito. Conforme se modificava a estrutura econômica do capitalismo, que não mais era concorrencial, senão monopolista, perdia-se o motivo de ser do caráter racional do direito. A burguesia monopolista, articulada por trustes e holdings que aglomeravam inúmeros ramos da produção, inclusive bancos investidores, acumulava poder econômico suficiente para renunciar à racionalidade das leis gerais, que lhe eram, na verdade, empecilhos ao desenvolvimento. Noções de equidade e cláusulas indeterminadas, em processos judiciais com grande disparidade de recursos entre as partes, favoreceriam os grandes conglomerados no ato judicial de fixação do significado dos termos vagos. Ademais, medidas individuais do poder executivo fomentavam desenvolvimentos dos monopólios de maneira imprevisível no Império das Leis - comente-se: principalmente se advindas de um estado totalitário que fornecia o povo judeu como mão de obra escrava e como cobaias humanas.

A consequência disso é que, no âmbito da economia monopolista, as cláusulas gerais servem essencialmente aos interesses dos monopolistas. A norma irracional é calculável para o monopolista, já que é forte o bastante para renunciar à racionalidade formal. $\mathrm{O}$ monopolista não só pode viver sem o direito racional, mas ele é ainda frequentemente uma algema para o completo desenvolvimento ou para a limitação das forças produtivas que lhe é oportuna (NEUMANN, 2014, p.72).

E para demonstrar essa transformação no direito - de lei geral, ou conceitos determinados, para cláusulas indeterminadas e juízos de equidade -, Neumann fez um belo trabalho de coleção destas últimas dentro do direito alemão, demonstrando os interesses monopolistas imiscuídos no direito do trabalho, no direito do consumidor, etc.

No direito do trabalho alemão, por exemplo, a admissibilidade da greve era julgada pela cláusula geral do $\S 826$ do Código Civil, que afirmava: "quem causar danos a outrem de forma atentatória aos bons costumes está obrigado a pagar indenização." (NEUMANN, 2014, p.68), Segundo Neumann, que foi advogado trabalhista, não seria possível alcançar uma interpretação única sobre essa regra geral que se balizava pelo impreciso termo "bons costumes", o que deixava os trabalhadores à mercê do casuísmo e propícios às arbitrariedades dos juízes, que eram pressionados ao julgar causas de conglomerados poderosíssimos. Não haveria sequer um mínimo 
de igualdade, previsibilidade, liberdade, como o direito liberal racional se propunha a garantir. Nesse exemplo do direito do trabalho alemão, essa mudança da forma do direito seria providencial à satisfação dos interesses burgueses monopolistas na medida em que "a redescoberta das cláusulas gerais serv[iu] à destruição de um direito positivo que tinha incorporado partes consideráveis da reforma social" (NEUMANN, 2014, p.70). Com a inserção de cláusulas indeterminadas, o direito alemão ruiu com o trabalhismo e o sindicalismo de Weimar, cuja legislação se estruturava por conceitos determinados, de linguagem concreta e precisa.

\section{Virtudes da filosofia jurídica de Neumann.}

A constatação da mudança da função e da estrutura do direito, na passagem do capitalismo concorrencial para o monopolista, realizada por Neumann, presta relevantes serviços à análise crítica marxista sobre direito, ao denunciar a inexistência de "progressividade" em filosofias jurídicas mais principiológicas, como já expunha Neumann ao tratar da "Escola de Direito Livre", e que hoje são defendidas pelos autores do chamado pós-positivismo.

Antes de 1918, a Escola de Direito Livre exigia poder discricionário para o juiz para implementar ideias progressistas num sistema reacionário. Mas Max Weber já advertia em 1911: "Aliás, não sabemos com certeza se as atuais classes negativamente privilegiadas, especialmente a classe trabalhadora, podem esperar, para seus interesses, da justiça não formal aquilo que supõe a ideologia dos juristas" (NEUMANN, 2014, p.67).

Desde a Escola de Direito Livre, se reverbera nas teorias jurídicas essa ideia de que os conceitos indeterminados e a interpretação judicial seriam capazes de inserir tons "progressivos" dentro da legalidade, âmbito dominado pelo poder legislativo classista e reacionário. Naturalmente, cada pensador possui suas nuances. Contemporaneamente, a teoria do direito tem se desenvolvido em constante censura ao positivismo jurídico e ao direito liberal pós-revolução francesa. Mas fazem a critica errada. A noção de princípio, por exemplo, do "primeiro Dworkin", dos livros Levando os direitos a sério e Uma questão de princípios, possibilita, em processos judiciais, espaços de abertura à discricionariedade com a qual os juízes podem ceder à ideologia e aos interesses burgueses, que se sobreporiam a direitos dos trabalhadores.

Mas além do pós-positivismo americano, é necessário um olhar crítico ao desenvolvimento da teoria do direito proveniente do continente europeu. Por exemplo, no texto $A$ justiça, inserido, posteriormente, no livro Ética e Direito, Chaïm Perelman elencou seis possíveis regras de justiça que, segundo ele, tradicionalmente funcionaram de base para pensamentos jurídico-filosóficos, como: "a cada um segundo seu esforço", "a cada um a mesma coisa", etc. 
Neste texto, o autor concluiria pela arbitrariedade na escolha por uma dentre essas regras. Mais tarde, em Tratado da Argumentação e em Lógica Jurídica, a base comum de um auditório valores idealmente compartilhados - confeririam a preferência por uma ou outra regra de justiça dentro de um auditório, o que eliminaria a arbitrariedade por referência a uma espécie de Cultura Jurídica. Esses valores, no Lógica Jurídica, são expostos em topóis que deveriam servir para legitimar interpretações jurídicas corretas em confronto a outras possíveis erradas.

Neumann, porém, com recurso materialista à imanência histórica do direito, demonstrou que não é bem isso. Essa constatação de Neumann é valiosíssima, pois desvela o estranhamento existente entre os sujeitos e essas regras de justiça historicamente constituídas. Como diria Karl Marx em Ideologia Alemã. "Não é a consciência que determina a vida, mas a vida que determina a consciência." (MARX, 2007, p.94). As regras de justiça não estão aí para a escolha livre de qualquer condição pré-existente ao homem, mas são condicionadas à forma como o homem faz a si mesmo historicamente. Por isso, ao contrário do que Perelman afirmava, as regras de justiça e os topóis não "preenchem" a noção de "equidade" a partir de um senso comum dado culturalmente pelo auditório a partir de sua vontade livre. O conteúdo do "justo" é condicionado pelo modo de produção da vida dado historicamente. A noção de equidade (ou justiça) dominante atualmente é a burguesa.

A justiça das transações que se efetuam entre os agentes da produção baseia-se na circunstância de se originarem das relações de produção como consequência natural. As formas jurídicas em que essas transações econômicas aparecem como atos de vontade dos participantes, como expressão de sua vontade comum e como contratos cuja execução pode ser imposta à parte individual por meio do Estado não podem, como simples formas, determinar esse conteúdo. Elas apenas o expressam. Esse conteúdo será justo contando que corresponda ao modo de produção, que lhe seja adequado. E injusto, assim que o contradisser. A escravatura, na base do modo de produção capitalista, é injusta; da mesma maneira a fraude na qualidade da mercadoria (MARX, 1986, p.256).

Por isso, a denúncia de Neumann é importante à tradição marxista. O autor foi à busca das condições materiais dentro do capitalismo para demonstrar que a mudança da forma jurídica (de leis gerais cedendo lugar às clausulas indeterminadas e às noções de equidade) correspondia aos interesses da burguesia monopolista. Enquanto marxistas, acrescentamos: não é possível, como supõem os teóricos do pós-positivismo, esperar bom resultados do arbítrio dos juízes, grandes burocratas do Estado burguês, ao delimitarem, nos casos concretos, o significado dos conceitos indeterminados. Suas ideologias são, em regra, as ideologias da classe dominante. Comente-se: a exemplo do que fizera a comuna de Paris, eis a tarefa revolucionária: "Tal como os demais servidores públicos, os magistrados e juízes deviam ser eletivos, responsabilizáveis e demissíveis" (MARX, 2011, p.57), “com redução dos vencimentos de todos os funcionários do 
Estado [inclusive juízes] para o nível dos 'salários de operário"” (LÊNIN, 2017, p.66, grifos do autor).

As teorias pós-positivistas valorizam noções de equidade, razoabilidade, bem comum, princípios, etc, a depender das variantes dos pensadores. Inclusive, por via delas, o direito adquiriu uma legitimidade proveniente de ideologias "comunitaristas" e "culturalistas", que tem sido, como dito, apontada como um fenômeno "progressista" - com todo embaraço e contradições que esse termo "progressista" carrega consigo. Seduzem, com uma filosofia jurídica idealista, honestos pensadores de esquerda. Mas sequer a reformismos se valem a "equidade" [e variantes] defendida pelas teorias pós-positivistas.

Neumann, ademais, com textos escritos na primeira metade do século $\mathrm{XX}$, deixou prejudicadas também, de antemão, sociologias atuais do direito que não se atualizaram em relação à forma jurídica condicionada pelo estágio atual do capitalismo, como a de Pierre Bourdieu (1989, cap. 8), que também aproxima Marx a Weber na tentativa de afirmar ser o direito um campo parcialmente autônomo em relação ao poder econômico. Para Bourdieu, o conteúdo de classe inserido no direito pelo poder econômico ganharia relativa autonomia quando operacionalizada pela racionalidade formal. Sem entrar muito no mérito, Neumann, há quase meio século atrás, evidenciou o anacronismo de Bourdieu, que está a descrever o direito como leis gerais, predominante no capitalismo concorrencial, ao passo que hoje, no capitalismo monopolista, predominam as cláusulas indeterminadas e a "equidade", nas variantes dos "princípios", "senso comum", “auditório universal”, etc.

\section{Contradições e insuficiências da filosofia jurídica de Neumann.}

Mas a experiência nazista, que deve ser entendida em compasso com a monopolização da economia e com o fim do formalismo jurídico, deixou marcas negativas em Neumann. A despeito de verificar duas funções prejudiciais à emancipação humana que o direito liberal ocasionava (tornar o sistema econômico previsível e encobrir o poder da burguesia), o filósofo procurou resgatá-lo no pós-guerra com a finalidade de restaurar a democracia burguesa na Alemanha. Claramente, Neumann escolheu a terceira função do direito liberal frente àquelas duas: o mínimo de liberdade e igualdade da universalidade do direito liberal. Não há problema nenhum para um marxista em dimensionar potenciais no direito frente a regimes bonapartistas. Marx, em Sobre a questão Judaica, anotou as virtudes da "emancipação política" do Estado. O problema na 
atuação política de Neumann foi pretender resgatar o Império da Lei no pós-guerra, momento em que se abriam caminhos à emancipação humana para o povo alemão ${ }^{4}$.

Neumann, consciente das condições materiais do direito liberal na sociedade burguesa concorrencial, não poderia, porém, simplesmente reafirmá-lo sem cair no que ele próprio denominou voluntarismo utópico. Por isso, se esforçou para demonstrar que a democratização da Alemanha, seu objetivo, seria eficaz caso as relações sociais e econômicas que sustentavam o nazismo ruíssem, quais sejam, as grandes indústrias monopolistas. Nesse sentido afirmou Herbert Marcuse na introdução ao livro Estado Democrático e Estado Autoritário, que reúne textos de Neumann:

Foi no Institute of Social Research que Neumann escreveu o seu Behemoth, uma tentativa para identificar as raízes econômicas e políticas do totalitarismo na sociedade industrial contemporânea assim como as condições históricas de seu surgimento na Alemanha. Durante o tempo que trabalhou na Repartição de Serviços Estratégicos (Office of Strategic Services) de 1942 a 1946, Neumann aplicou o que ali havia aprendido para analisar e antecipar os acontecimentos na Alemanha. Dedicou os seus melhores esforços a planos para a democratização da Alemanha para que não se repetissem os fracassos da República de Weimar. Procurou demonstrar que a desnazificação, para ser eficaz, deveria ser mais do que purgação de pessoal e abolição de legislação nazista. Ela deveria chegar às raízes do fascismo alemão com a eliminação dos alicerces econômicos da política antidemocrática da grande indústria alemã (MARCUSE, 1969, p.8)

O resultado dos estudos de Neumann contribuiu para os objetivos americanos de desnazificação que ficaram compreendidos como os 4 (quatro) "Ds": desnazificação, democratização, desmilitarização e descartelização, sendo este último D condição para os demais. Conforme expôs Peter Hayes no prefácio ao Behemoth:

In 1943-1945, while Neumann was serving in Washington, D.C., in the Office of Strategic Services, the forerunner of the Central Intelligence Agency, his work strongly influenced the formulation of America's goals for postwar Germany as the " four Ds," each directed at one of the colluding groups he had highlighted: denazification, democratization (including the recruitment and training of civil servants), demilitarization, and decartelization (HAYES, 2009, p.VIII).

\footnotetext{
${ }^{4}$ Sobre as oportunidades revolucionárias abertas no pós-segunda guerra, ver As revoluções no século $X X$, de Nahuel Moreno. "La nueva etapa revolucionaria, que se inicia con la derrota en Stalingrado del ejército nazi y abre un período de revoluciones triunfantes que se extiende hasta el presente. La primera de ellas es la yugoslava; pasa por su máxima expresión con la revolución china, y ha tenido su última victoria (en el sentido de que se expropió a la burguesía y se construyó un estado obrero), hasta ahora, en Vietnam (1974). A esta etapa la hemos denominado de la "revolución inminente", porque, a diferencia de la etapa abierta por la revolución rusa, que redujo sus efectos a algunos países de Europa y Oriente, en ésta la revolución estalla, y em ocasiones triunfa, en cualquier parte del globo: los países semi coloniales o coloniales (China, Vietnam, Cuba, Irán, Angola, etc.), los propios países imperialistas (aunque todavía sólo en los más débiles, como Portugal) y en los estados obreros (Hungría, Polonia)" (MORENO, 1984, p.27-28)
} 
Para concluir este artigo, serão desenvolvidas duas críticas que têm por objetivos expor aporias do pensamento de Neumann e evidenciar o caráter pequeno-burguês na maneira como o filósofo alemão lida com elas. Por um lado, com Lênin, se evidenciará a incapacidade de o capitalismo retroceder ao patamar concorrencial, que permitiria a forma jurídica liberal ansiada por Neumann. Por outro lado, resgatando o próprio Marx, se demonstrará a insuficiência do direito liberal em promover a emancipação humana.

Em primeiro lugar, a evolução do capitalismo concorrencial para o monopolista é irreversível, como já demonstrou Lênin. Ponto de partida de Lênin no livro Imperialismo, etapa superior do capitalismo é a derrocada do capitalismo concorrencial, que se mantivera hegemônico até o terceiro quarto do século XIX, mas que, pelo desenvolvimento interno de suas próprias estruturas econômicas, culminou na monopolização. Para ilustrativamente explicar o processo de monopolização do capitalismo, pode-se dizer que indústrias que conseguiram maior destaque na situação inicial de concorrência acumularam capitais e puderam diminuir os custos da produção e inovar tecnologicamente. Por conseguinte, as que mais de desenvolveram nesse processo, hipoteticamente, contrataram mais operários, produziram mais e melhor e, por fim, aumentaram sua fração do mercado, se sobressaindo frente a outras indústrias menos desenvolvidas, que foram à falência. Esse processo é cíclico, o que permite às indústrias bem sucedidas obterem mais acumulação, reinvestimento, conquista de mercado, mais acumulação...

Esse caminho monopolizador do capitalismo é irreversível. Por evolução natural do capitalismo, tende-se à monopolização dos mercados, ao contrário das suposições liberais de livre mercado. Por isso, Neumann, que pretendia resgatar o patamar da época concorrencial, caiu no que ele próprio chamava de voluntarismo utópico ao tentar girar a roda da história para trás.

Há meio século, quando Marx escreveu O Capital, a livre concorrência era, para a maioria dos economistas, uma "lei natural". A ciência oficial procurou aniquilar, por meio da conspiração do silêncio, a obra de Marx, que tinha demonstrado, através de uma análise teórica e histórica do capitalismo, que a livre concorrência gera a concentração da produção, e que a referida concentração, num certo grau do seu desenvolvimento, conduz ao monopólio. Agora o monopólio se tornou um fato. Os economistas publicam montanhas de livros em que descrevem as diferentes manifestações do monopólio e continuam a declarar em coro que "o marxismo está refutado" (LÊNIN, 2011, p.124, grifos nossos).

Em busca de mais força e estabilidade, as grandes indústrias adquirem empresas produtoras de matéria-prima e implantam modernizações em infraestrutura e em transportes que lhes beneficiam a produção e sua circulação de mercadorias. Devido a toda essa logística que os trustes e holdings possuem, elas tendem a se tornarem ainda maiores. Em épocas de crises econômicas, a conjuntura tende ainda mais pela monopolização. Pequenos quebram e grandes se 
tornam gigantes: a produção se concentra. Esse processo de absorção das empresas menores pelas maiores culminou no choque de interesses entre grandes conglomerados e entre Estados nacionais que defendem os interesses das empresas sediadas neles. Nesse processo, o capitalismo perdeu o potencial de incrementar as forças produtivas e passou a destruí-las com as crises de superprodução e, no que imposta a este trabalho, com as guerras do imperialismo.

Almejar a um retorno ao capitalismo concorrencial para se restabelecer as bases do direito formal racional parece ser um voluntarismo utópico, ainda mais para quem estudou o imperialismo alemão, como é o caso de Neumann (Cf. 2009, parte 1, cap. 6), que ficara destituído da partilha neocolonial. Na linha de Lênin, afirma-se que Neumann capitulou à socialdemocracia pequeno burguesa da II Internacional, capitaneada pelo renegado Kautsky, que pretendia restaurar a idílica livre concorrência e, por conseguinte, retroceder o imperialismo e fortalecer o que hoje se chama Estado de Direito, a democracia burguesa.

O essencial na crítica do imperialismo consiste em saber se é possível modificar por meio de reformas as bases do imperialismo, se há que seguir para diante, agudizando e aprofundando ainda mais as contradições que o imperialismo gera, ou se há que retroceder, atenuando essas contradições. Como as particularidades políticas do imperialismo são a reação em toda a linha e a intensificação da opressão nacional - consequência da opressão da oligarquia financeira e da supressão da livre concorrência, a oposição democrática pequeno-burguesa ao imperialismo aparece em quase todos os países imperialistas em princípios do século XX. E a ruptura com o marxismo, por parte de Kautsky e da vasta corrente internacional do kautskismo, consiste precisamente em que Kautsky, além de não se preocupar, de não saber enfrentar, essa oposição pequenoburguesa, reformista, fundamentalmente reacionária do ponto de vista econômico, se fundiu praticamente com ela. Kautsky rompeu com o marxismo ao defender, para a época do capital financeiro, um "ideal reacionário", a "democracia pacífica", o "simples peso dos fatores econômicos", pois este ideal arrasta objetivamente para trás, do capitalismo monopolista para o capitalismo não monopolista, e é um engano reformista (LÊNIN, 2011, p.246-250).

E, em hipótese de restaurada a livre concorrência dos períodos iniciais do capitalismo e o seu direito liberal, não seria, por acaso, que o desenvolvimento interno da economia capitalista não culminaria novamente nos monopólios?

Os raciocínios de Kautsky não podem ter outro sentido, e este "sentido" é um sem sentido. Admitamos que sim, que a livre concorrência, sem monopólios de nenhuma espécie, poderia desenvolver o capitalismo e o comércio mais rapidamente. Mas quanto mais rápido é o desenvolvimento do comércio do capitalismo, mais intensa é a concentração da produção e do capital que gera o monopólio. E os monopólios nasceram já, precisamente da livre concorrência! Mesmo se os monopólios refrearam atualmente o seu desenvolvimento, isto não é, apesar de tudo, um argumento a favor da livre concorrência, que se tornou impossível depois de ter gerado os monopólios. Por mais voltas que se dê aos raciocínios de Kautsky, não se encontrará neles mais do que reacionarismo e reformismo burguês (LÊNIN, 2011, p.250). 
Os conceitos jurídicos indeterminados e o capitalismo monopolista sobreviveram. O julgamento da história confere razão a Lênin e renegam Neumann à utopia reformista. Aqui já estão cumpridos os objetivos deste artigo. Adicionalmente, há ainda espaço para uma segunda crítica à filosofia jurídica de Neumann, sem contar outras possibilidades. Não pretendemos ser exaustivos. É necessário lembrar a Neumann os limites, percebidos por Marx, do direito liberal em realizar a tarefa da emancipação humana. Desde Hegel, não há dúvida entre os marxistas acerca do caráter putrefato da sociedade civil burguesa: "o espetáculo da devassidão bem como o da corrupção e da miséria" (HEGEL, 1997, p.169). O direito, para Hegel, teria a potencialidade de contribuir na reconciliação das contradições das carências individuais de cada sujeito pertencente à sociedade civil. Não resta dúvida, porém, por todo exposto neste trabalho, que o direito, na visão marxiana, apenas reconhece a devassidão da sociedade civil burguesa. É post-factum, o reconhecimento oficial do fato. "Suas ideias são produto das relações burguesas de produção e de propriedade, assim como o Direito não é nada mais do que a vontade de sua classe erigida em lei, uma vontade cujo conteúdo é determinado pelas condições materiais de vida de sua própria classe" (MARX; ENGELS, 2008, p.36).

Isso não significa que o direito não tenha, para Marx, algum potencial, mas o possui tão somente enquanto reconhecimento de lutas sociais. O próprio Marx afirmou acerca do direito: "tal regulamentação foi o primeiro freio racional aplicado aos volúveis caprichos da moda, homicidas carentes de sentido e por sua própria natureza incompatíveis com o sistema da grande indústria" (MARX, 2017, p.550). Com relação à temática dos direitos trabalhistas, para dialogar com exemplo retirado de Neumann no final da seção 2 acerca do trabalhismo da república de Weimar, Marx defendia aprovação de leis que garantissem melhores condições de luta ao operariado explorado:

[...] para 'se proteger' contra a serpente de suas aflições, os trabalhadores têm de se unir e, como classe, forçar a aprovação de uma lei, uma barreira social intransponível que os impeça a si mesmos de, por meio de um contrato voluntário com o capital, vender a si e a suas famílias à morte e à escravidão (MARX, 2017, p.373-374).

Nota-se, a partir das duas últimas citações, que o próprio Marx reconhece algum valor, embora pouco, ao "freio racional" que o direito formal pode proporcionar ao reconhecer o fruto das lutas de classes. Não obstante as potencialidades que dele emergem devem servir a novas lutas sociais pela emancipação humana. Não são o ponto de chegada. O que Neumann faz é justamente se satisfazer com o mínimo de liberdade, aceitando como efeito colateral inevitável o que ele diagnosticou como a dominação de classes sobre o direito e a véu ideológico posto pela universalidade formal. 
Para Marx, o potencial jurídico é insuficiente para a emancipação humana. A igualdade burguesa, possível dentro do Estado politicamente emancipado, é regra de justiça que só faz sentido dentro do modo de produção capitalista, sendo injusta na conjecturada sociedade comunista ${ }^{5}$. Possuir direitos, uma esfera inatingível à vontade alheia, avanço histórico positivo de certa maneira, mantém o homem isolado enquanto produto da sociedade civil burguesa egoísta, algo totalmente distante da perquirida emancipação humana, quando indivíduos poderão se relacionar em sociedade sem se reificarem como meio para satisfação de suas carências ou se isolarem egoisticamente como cidadãos portadores de direitos. Marx, em Crítica ao programa de Goetha:

Por isso, aqui, o igual direito é ainda, de acordo com seu princípio, o direito burguês,(...). Apesar desse progresso, esse igual direito continua marcado por uma limitação burguesa. O direito dos produtores é proporcional a seus fornecimentos de trabalho; a igualdade consiste, aqui, em medir de acordo com um padrão igual de medida: o trabalho. (...) Ele não reconhece nenhuma distinção de classe, pois cada indivíduo é apenas trabalhador tanto quanto o outro; mas reconhece tacitamente a desigualdade dos talentos individuais como privilégios naturais e, por conseguinte, a desigual capacidade dos trabalhadores. Segundo seu conteúdo, portanto, ele é, como todo direito, um direito da desigualdade. $\mathrm{O}$ direito, por sua natureza, só pode consistir na aplicação de um padrão igual de medida; mas os indivíduos desiguais (e eles não seriam indivíduos diferentes se não fossem desiguais) só podem ser medidos segundo um padrão igual de medida quando observados do mesmo ponto de vista, quando tomados apenas por um aspecto determinado, por exemplo, quando, no caso em questão, são considerados apenas como trabalhadores e neles não se vê nada além disso, todos os outros aspectos são desconsiderados. Além disso: um trabalhador é casado, o outro não; um tem mais filhos do que o outro etc. etc. Pelo mesmo trabalho e, assim, com a mesma participação no fundo social de consumo, um recebe, de fato, mais do que o outro, um é mais rico do que o outro etc. A fim de evitar todas essas distorções, o direito teria de ser não igual, mas antes desigual. Mas essas distorções são inevitáveis na primeira fase da sociedade comunista, tal como ela surge, depois de um longo trabalho de parto, da sociedade capitalista. $\mathrm{O}$ direito nunca pode ultrapassar a forma econômica e $\mathrm{o}$ desenvolvimento cultural, por ela condicionado, da sociedade. Numa fase superior da sociedade comunista, quando tiver sido eliminada a subordinação escravizadora dos indivíduos à divisão do trabalho e, com ela, a oposição entre trabalho intelectual e manual; quando o trabalho tiver deixado de ser mero meio de vida e tiver se tornado a primeira necessidade vital; quando, juntamente com o desenvolvimento multifacetado dos indivíduos, suas forças produtivas também tiverem crescido e todas as fontes da riqueza coletiva jorrarem em abundância, apenas então o estreito horizonte jurídico burguês poderá ser plenamente superado e a sociedade poderá escrever em sua bandeira: "De cada um segundo suas capacidades, a cada um segundo suas necessidades!" (MARX, 2012, p.31, grifos nossos).

\footnotetext{
5 Marx, fiél ao materialismo histórico, não se afastava da realidade da sociedade capitalista para fazer futurologia, sobre como seria supostamente a sua superação com advento do comunismo. Quando algo disse acerca do comunismo, ao estudar (MARX, 2011), a Comuna de Paris (1871), analisava tendências a partir da nova sociedade que o proletariado criava naquela revolução. Essa experiência foi significativa para, mais tarde, em Crítica ao programa de Goetha, fazer algumas abstrações razoáveis acerca da sociedade comunista.
} 
Neumann enxergava a saída para a emancipação humana na radicalização dos direitos liberais, expandindo a lógica do direito burguês a garantias sociais, como direitos trabalhistas e previdenciários, algo que já se mostrou insuficiente com a Crítica ao Programa de Goetha. Embora marxista na leitura (em termos gerais) da sociedade capitalista, Neumann capitulou ao reformismo na sua proposta de modificação.

Assim como seu mestre Harold Laski, Neumann, embora tivesse passado a aderir a uma teoria marxista da sociedade, continuava, politicamente, sendo um reformista que punha todas as suas esperanças numa política melhor dos movimentos operários no contexto de um Estado de direito restabelecido (WIGGERHAUS, 2002, p.253).

\section{Conclusões.}

Um resgate da filosofia do direito de Franz Neumann permite recolocar em melhores termos os problemas com os quais a teoria contemporânea do direito lida ordinariamente. O modo de pesquisa histórico-materialista de Neumann evidencia que princípios, juízos de equidade, boafé, entre tantas outras variantes dos conceitos jurídicos indeterminados propostas pelas teorias jurídicas e inseridas na forma do direito positivo atuais, não possuem cunho "progressista" algum. Pelo contrário, historicamente surgiram para conciliar o direito ao estágio monopolista do capitalismo, que surgia no último quartel do século XIX. A percepção de Neumann, portanto, é valiosa ao pesquisador marxista na medida em que desvela a esterilidade do debate das teorias jurídicas contemporâneas.

Mas o pensador alemão falhou veementemente no passo seguinte, que seria ultrapassar os limites do direito burguês para alcançar a emancipação humana, reafirmando a necessidade da revolução socialista e da superação do capitalismo. Ao contrário, Neumann pretendia girar a roda da história para trás em um reformismo pequeno-burguês. Sua proposta de retorno às leis gerais e conceitos determinados, e sua defesa ao capitalismo concorrencial, o fazem capitular ao que ele mesmo chamou de voluntarismo utópico - pretensão de mudar a sociedade por meio de fraseologias e políticas irrealizáveis nas condições sociais existentes. Embora materialista, Neumann caiu nas armadilhas pequeno-burguesas: o capitalismo é em essência monopolizador; a proposta jurídica do filósofo é uma utopia reformista. 


\title{
Law between class domination and rationality in Franz Neumann
}

\begin{abstract}
The Third Reich provoked traumatic reflexes in the Franz Neumann's legal and political philosophy. Under the influence of the Marxist historical-dialectical materialism, the philosopher understood the law as the official recognition of the social and economic relationships that had arisen with the capitalism. However, at the same time, the Nazi dictatorial regime and the transformations through which the legal technique was passing, both made possible by the monopoly capitalism, made him extol the liberal law of the period of the competitive capitalism, which possessed what the philosopher called "the minimum of rationality". This work starts from this tension in Neumann's legal philosophy, which criticizes law as class domination, but also sees in it a positive dimension due to its possibility of "rationality". The article indicates the virtues of Neumann for elaborating his legal philosophy in a materialistic research method and ends, critically, based on Marx and Lenin, pointing out his contradictions and insufficiencies.
\end{abstract}

Keywords: Franz Neumann; Law; Marxism; Imperialism; Leninism. 


\section{Referências Bibliográficas.}

BOURDIEU, Pierre. O poder simbólico. Trad. Fernando Tomaz. São Paulo: Bertrand Brasil: 1989.

DWORKIN, Ronald. Levando os direitos a sério. Tradução de Nelson Boeira. São Paulo: Martins Fontes, 2002. 2001. . Uma questão de princípio. Tradução de Luis Carlos Borges. São Paulo. Martins Fontes,

ENGELS, Friedrich. Anti-Dühring. Trad. Nélio Schneider. Apresentação de José Paulo Netto. São Paulo: Boitempo, 2015.

ENGELS, Friedrich; KAUTSKY, Karl. O socialismo jurídico. Trad. Lívia Contrim e Márcio Bilharinho Naves. São Paulo: Boitempo, 2012.

HAYES, Peter. Introduction. In: NEUMANN, Franz. Behemoth: The structure and pratice of national socialism (1933 - 1944). Chicago: Ivan R. Dee, 2009.

HEGEL, G. W. F. Princípios da filosofia do Direito. Trad. Orlando Vitorino. São Paulo: Martins Fontes, 1997.

JAY, Martin. A imaginação dialética: história da escola de Frankfurt e do instituto de pesquisas sociais - 1923-1950. Trad. Vera Ribeiro e César Benjamin. Rio de Janeiro: Contraponto, 2008.

LÊNIN, Vladimir Ilitch. Imperialismo: etapa superior do capitalismo. Campinas: Unicamp, 2011.

. O Estado e a Revolução. Trad. Paula Almeida. São Paulo: Boitempo, 2017.

LOCKE, John. Dois tratados sobre o governo. Trad. Júlio Fischer. São Paulo: Martins Fontes, 1998.

MARCUSE, Herbert. Prefácio. In: MARCUSE, Herbert (Org.), NEUMANN, Franz. Estado democrático e Estado autoritário. Tradução de Luiz Corção. Rio de Janeiro: Zahar Editores, 1969.

MARX, Karl. A guerra civil na França. Trad. Rubens Enderle. São Paulo: Boitempo, 2011. 2012.

. Crítica ao programa de Goetha. Tradução de Rubens Enderle. São Paulo: Boitempo,

Miséria da filosofia. Tradução de José Paulo Netto. São Paulo: Boitempo, 2017.

O 18 Brumário de Luís Bonaparte. Trad. Nélio Schneider. São Paulo: Boitempo, 2001. 
. O capital. Vol. IV. Tradução de Regis Barbosa e Flávio R. Kothe. São Paulo: Nova Cultural, 1986.

. O capital. Livro I. Tradução de Rubens Enderle. São Paulo: Boitempo, 2017.

. Sobre a questão Judáica. Inclui as cartas de Marx a Ruge publicadas nos Anais FrancoAlemães. Apresentação e posfácio de Daniel Bensaïd. Tradução de Nélio Schneider e Wada Caldeira Brant. São Paulo: Boitempo, 2010.

MARX, Karl; ENGELS, Friedrich. Cultura, arte e literatura: textos escolhidos. Tradução de José Paulo Netto. São Paulo: Expressão popular, 2010.

. Ideologia Alemã. Tradução Rubens Enderle, Nélio Schneider e Luciano Martorano. São Paulo: Boitempo, 2007.

. Manifesto Comunista. Traduzido por Posvaldo Coggiola. São Paulo: Boitempo, 2008,

MORENO, Nahuel. Las revoluciones del siglo XX. Buenos Aires, Cuadernos de Solidaridad Socialista, 1984

NEUMANN, Franz. A mudança de função da lei no direito da sociedade burguesa. Revista Brasileira de Estudos Políticos. n. 109, pp. 13-87. jul/dez 2014.

R. Dee, 2009.

. Behemoth: The structure and pratice of national socialism (1933-1944). Chicago: Ivan

. O conceito de liberdade política. Cadernos de Filosofia Alemã, n. 22, pp.107-154.

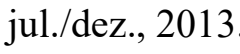

PERELMAN. Chaïm. Ética e Direito. Tradução de Maria Ermantina de Almeida Prado Galvão. São Paulo: Martins Fontes, 1996.

Lógica Jurídica. Tradução de Virgínia K. Pupi. São Paulo:Martins Fontes, 1998.

PERELMAN. Chaïm; OLBRECHTS-TYTECA, Lucie. Tratado de argumentação: a nova retórica. Tradução de Maria Ermantina de Almeida Prado Galvão. $2^{\circ}$ ed. São Paulo: Martins Fontes, 2005.

POSTONE, Moishe. Crítica, Estado e Economia. In: RUSH, Fred (Org.). Teoria Crítica. Trad. Beatriz Katinsky e Regina Andrés Rebollo. 2.ed. Aparecida: Ideias \& Letras, 2008, p.203-234.

SCHEUERMAN, Willian F. Introduction. In: SCHEUERMAN, Willian F (Org.); NEUMANN, Franz; KIRCHHEIMER, Otto. The rule of law under siege. Berkeley: University of California Press, 1996.

WIGGERHAUS, Rolf. A Escola de Frankfurt: história, desenvolvimento teórico e significação política. Trad. de Lilyane Deroche-Gurgel e Vera de Azambuja Harvey. Rio de Janeiro: DIFEL, 2002. 
Trabalho recebido em 28 de novembro de 2018

Aceito em 24 de fevereiro de 2019 